\title{
Effects of Different Classroom Activities on the English Speaking Proficiency of Chinese EFL Students
}

\author{
Hangyu Zhang* \\ Postgraduate student in Shanghai International Studies University (Applied Linguistics) \& Monash University
}

(TESOL)

\begin{abstract}
*Corresponding Authors: Hangyu Zhang, Postgraduate student in Shanghai International Studies University (Applied Linguistics) \& Monash University (TESOL)
\end{abstract}

\begin{abstract}
Previous research findings have identified the importance of speaking proficiency in English learning and teaching, and class activities can exert significant effects on learners' speaking proficiency. Therefore the purpose of this study is to answer the question "What effects should different classroom activities have on the English speaking proficiency of Chinese EFL students?" by collecting evidence from previous studies and literatures. Through detailed discussion and connection among the evidence, the study finally concludes three factors relating to anxiety, interaction, and motivation that contribute to the effectiveness of classroom activities on English speaking proficiency.
\end{abstract}

Keywords: activities; English speaking proficiency; anxiety; interaction; motivation

Abbreviation: EFL (English as a foreign language)

\section{INTRODUCTION}

Speaking proficiency has identified to be important in English learning and teaching. Hedge (2001) Claimed that it's a priority to learn to speak competently in English for many students because of their willingness to keep up rapport in different relationships and influence people in communication. Upon this account, considerable attention has been paid to a variety of classroom activities in an English speaking class (Huang, \& Hu, 2016). However, there has been evidence showing that different situations in classroom activities exert various effects on leaners' English speaking proficiency (Humphries, Burns, \& Tanaka, 2015). This fact indicates that both positive and negative effects can be made according to the types and features of classroom activities. For instance, Oradee (2012) found that communicative activities such as discussion, problem-solving, and role play can develop students' English speaking proficiency, while Lim (2017), after his investigation, argued that some oral activities in EFL classes such as some drill activities possibly cause the low English speaking proficiency for students. Under this background, to answer the question "What effects should different classroom activities have on the English speaking proficiency of Chinese EFL students?" is of great significance. By finding the answer to this question, it might contribute to the development or the design of classroom activities so as to make activities more useful in improving students' speaking proficiency. Here EFL students refer to students taking English as a foreign language, which is distinguished from the acquisition of first language.

Through the analysis of previous evidence and reviewing literature, the main argument in this essay is International Journal on Studies in English Language and Literature (IJSELL) 
that classroom activities can have different effects on Chinese EFL students' English speaking proficiency and effective activities should be conducive to students in reducing speaking anxiety, encouraging speaking interaction and enhancing speaking motivation. Actually, the existence of different effects has been mentioned above, but evidence is given in the following essay to further support this argument. Then, evidence is presented and analyzed from three perspectives in order including speaking anxiety, speaking interaction, and speaking motivation. At the end of this essay is a conclusion part summarizing the whole study and presenting several implications.

\section{Different Effects of Classroom Activities on SPeaking Proficiency}

Apart from the evidence found by Oradee (2012) and Lim (2017), Huang and Hu (2016) examined 21 different classroom activities to help with the design of classroom activities for English speaking classes. Their study selected 100 participants including English- major freshmen, sophomores and teachers and was conducted by means of questionnaire with five-point Likert scale. Besides, one of them also observed two speaking classes for one month. After data collection and analysis, the results showed a great difference between different classroom activities. Although this study, as a quantitative analysis, only chose 100 participants, which may decrease the reliability and representativeness of the results, it can be applied as an evidence to support the fact of different effects of classroom activities because it covered a wide range of people and the questionnaire was designed scientifically and reasonably.

In addition, the existence of different effects of classroom activities can be proved with the following case study, which is totally different from last one. Zhang and Head (2009) conducted a study mainly describing the change of students' performance in an English speaking class. To be more specific, students involved in this case, who had been quite resistant to participating in speaking activities and whose achievements in speaking proficiency had been really disappointing before, acted actively after the teacher making a decision to involve them in designing activities and changing the forms of activities (Zhang, \& Head, 2009). This study proves the effectiveness of changing the design of activities in an English speaking class, showing the opposite effects of the classroom activities before and after changing.

To sum up, previous studies have shown a transverse contrast among different activities (Lim, 2017; Huang \& Hu, 2016; Oradee, 2012), as well as a longitudinal contrast (Zhang \& Head, 2009). Therefore, it can be argued that different classroom activities have different effects on EFL students' speaking proficiency.

\section{REDUCING SPEAKING ANXIETY}

\subsection{The Impact of Speaking Anxiety}

There has been an argument that language learning is a stressful situation for some students and the less anxious and more relaxed the learner is, the better his language acquisition proceeds (Chou, 2018; Huang, \& Hung, 2013; Tsiplakides \& Keramida, 2009). Tsiplakides and Keramida (2009) noticed a phenomenon that teachers often failed to identify anxious students and forced them to participate in speaking tasks, and conducted a study to establish a link between performance and language anxiety for English learners. The data suggested that English language speaking anxiety caused students' unwillingness to participate in practice and activities because of low self confidence (Tsiplakides \& Keramida, 2009). Based on this finding, arguably students with great anxiety could hardly open their mouths confidently and may not have a high speaking proficiency due to the lack of experience from practice. To further explore the impact of speaking anxiety, it can be learned from the following investigation that higher anxiety can lead to low efficiency in learning English speaking skills. Chou 
(2018) investigated English learners' speaking performance, anxiety, difficulties, and strategies in full and partial EMI contexts by using a questionnaire survey with an open-ended question, and speaking tests, showing that the context enabling students to have lower speech anxiety and more confidence in speaking could make them more positive in learning and willing to practice speaking. To be honest, the major aim of this study was not focused on anxiety, but to explore the influence of two contexts. Nevertheless, the quantitative and qualitative data collected in the process clearly revealed the negative impact of speaking anxiety on speaking skills. Moreover, Huang and Hung also reported the negative effects of speaking anxiety by investigating from a perspective of speaking tests. Taking the above evidence into full consideration, it can be concluded that speaking anxiety is supposed to have a negative impact on English learners' speaking proficiency.

\subsection{Effective Classroom Activities: Reducing Speaking Anxiety}

Since anxiety mainly plays a negative role in English speaking, designers of classroom activities are supposed to take this into account. Besides, several scholars have found that different classroom activities are able to impact students' speaking anxiety differently (Humphries,Burns,\& Tanaka, 2015;Mak, 2011, Tsiplakides, \& Keramida, 2009). Mak (2011) reported his findings relating to factors contributing to the English speaking anxiety in class of 313 Chinese ESL (English as a Second Language) students. According to the survey, some factors in activities such as in-adequate wait-time, and being without preparation can lead English learners to speaking-in-class anxiety and teachers should create low-anxiety classroom (Mak, 2011). This study was conducted from the perspective of English learners, which directly revealed the negative effects classroom activities could exert on learners' speaking anxiety. From this point of view, it can be inferred that if the above factors can be solved correctly, classroom activities are able to reduce students' anxiety in speaking English. Actually this inferred idea can be supported by the next study. Similarly, Humphries, Burns and Tanaka (2015) also conducted a survey on situations that increased and decreased EFL learners' speaking capacity and found some negative factors. Additionally, they also raised some strategies as solutions in designing classroom activities such as developing a supportive atmosphere to reduce anxiety and increase confidence, and showing empathy and flexibility to students' needs (Humphries, Burns and Tanaka, 2015). With the support from the above evidence, it can be concluded that classroom activities have different effects on speaking anxiety and there is a possibility for activities to reduce EFL learners' speaking anxiety.

Consequently, in virtue of the negative effects of speaking anxiety and activities' function of reducing anxiety, it can be argued that effective classroom activities are supposed to reduce EFL learners' speaking anxiety.

\section{INTERACTION}

\subsection{The Importance of Interaction}

The importance of interaction in language teaching and learning has been emphasized since long time ago (Allwright, 1984). And recently, a number of scholars worldwide have attached great importance to interaction in language learning in their studies (Brittain, 2017; Anjomshoa, \& Sadighi, 2015; Smith, \& Higgins, 2006; Sigley, 2003). Brittain (2017) reported in his study that the lack of meaningful interaction can limit the development of English language skills. Although his study was focused on immigrant EFL students, it can be applied into the present study because Chinese students were also a major part in those immigrant adolescents. More specifically, Pattanpichet (2011) made an experimental study in which the importance of interaction could be identified in a more direct way. This experiment was conducted by a pre-test and post-test design to examine EFL learners' speaking 
proficiency before and after collaborative learning that provided learners' more interaction, negotiation and sharing (Pattanpichet, 2011). The experiment results clearly demonstrated that the use of collaborative learning with more interaction contributed to learners' improvement on their English oral performance and qualitative data relating to learners' perceptions presented positive attitude towards it (Pattanpichet, 2011). Simultaneously, other scholars also put forward in their study that using interactive techniques in learning English is contributing and helps students develop speaking skills (Bashir, Azeem, \& Dogar, 2011). Despite the fact that these studies were not conducted in Chinese context, they are useful to the present study because it is a worldwide recognition that oral interaction provides one of the main sources of data for language acquisition (Lim, 2017), regardless of human species. The findings of these scholars in various studies are in accordance with each other generally, which further proves the reliability of these evidence to support the idea in the present study that interaction is of great importance for EFL learners, especially in English speaking skills.

\subsection{Effective Classroom Activities: Encouraging Speaking Interaction}

As interaction is conducive to EFL learners' speaking proficiency, it becomes a necessity for classroom activities to contribute to this factor. Previous studies have been conducted regarding this perspective (Oradee, 2012; Lim, 2017). Oradee (2012) made research on the evaluation and comparison of three communicative activities including Discussion, Problem-solving, and Role-playing. After a pretest of English speaking ability, participants were arranged to join lessons with different activities before the collection of their feedback and a post-test. It was presented after data analysis that these activities exerted positive effects on the progression in their speaking ability by providing more interaction, activating motivation and strengthening confidence (Oradee, 2012). This study took advantage of both qualitative and quantitative analysis to confirm the advantages of communicative activities with more interaction in English speaking proficiency, which, accordingly, helps the present study to conclude that students' intensive interaction in activities such as problem-solving and role play are effective in developing speaking English proficiency. On the other hand, Lim (2017) made a detailed critique on activities that were not effective in improving English speaking and argued that peer-interaction should be encouraged in activities as one of the solutions. Collectively, the evidence seems to indicate that some classroom activities are able to encourage students' speaking interaction so as to promote their speaking proficiency.

Overall, knowing the importance of interaction, effective classroom activities are supposed to encourage EFL learners' speaking interaction.

\section{Motivation}

\subsection{The Significance of Motivation}

There has been a claim made by psycho-linguists after their research that motivation can play a pivotal role in language learning (Dornyei, Alastair, \& MacIntyre, 2015). Such a claim can be confirmed by the research findings that EFL learners' obstacles to speak the language can be from internal factors, such as learners' low motivation (Abrar, Mukminin, Habibi, Asyrafi, Makmur, \& Marzulina, 2018). Moreover, there have been convincing data to prove the significance of motivation in a more direct way. According to an investigation on the correlation between motivation and English speaking ability, the results illustrated that the coefficient correlation was 0.780 , larger than the r-table of 0.334 , standing for significant correlation, and motivation influenced speaking ability positively with the score of $60.8 \%$ (Rahman, \& Deviyanti, 2018). Although the research data was collected only from 36 EFL students, which was not enough to support a quantitative analysis, the results obtained could be used as the empirical verification of the above claim. Consequently, the argument of the present study is made 
based on the claim that motivation plays a significant role in the development of English speaking proficiency.

\subsection{Effective Classroom Activities: Enhancing Speaking Motivation}

Liu and Chu (2010) reported the results of their study on investigating the influence of ubiquitous games on learning achievement and motivation in Chinese EFL learners' English listening and speaking, showing the effectiveness of gaming activities in learning process. Since the study integrated methods of experiment, testing, interviewing, and conducting a survey, its results were relatively comprehensive to highlights the function of such gaming activities in improving achievement and enhancing motivation. In the same year, another study was completed relating to arousing motivation though a certain activity. Liu (2010) adopted collection methods including observation, questionnaire and interview and used these data to prove that EFL students with role-play activities were more interested in English speaking. Different from the former study, this study was designed particularly for investigating the motivation in English speaking and it drew people's attention to the function of certain classroom activities in motivating English learners. However, both the two studies were focused on one particular teaching activity or method in EFL classroom, while Talley and Hui-Ling (2014) discussed an overall approach to the explicit and implicit teaching process in EFL classroom for English speaking and suggested that teachers were supposed to encourage students' willingness to participate in activities. In this way, teachers should not force students to participate, instead, they may apply some activities that are more attractive to arouse students' motivation and using some encouraging utterance in class.

On the basis of the recognition o the significance of motivation and the examples of successful classroom activities as evidence, effective classroom activities are supposed to enhance EFL learners' speaking motivation.

\section{CONCLUSION}

In order to answer the investigation question that "What effects should different classroom activities have on the English speaking proficiency of Chinese EFL students?", the present essay collected evidence from previous studies and experiments and made a discussion on the relevant evidence so as to argue for the existence of different effects of classroom activities on Chinese EFL learners' speaking proficiency and to claim that effective activities should be conducive to students in reducing speaking anxiety, encouraging speaking interaction and enhancing speaking motivation. The argument has been supported by coherent and logical evidence listed and analyzed in the former section.

By completing this study and making this argument, the present study may have the following implications. First of all, this study provides an opportunity to advance the understanding of effective classroom activities and sheds light on the identification of positive and negative factors in improving English speaking proficiency. In the second place, there is the possibility that this study may draw researchers attention to the exploration of the quality and influence of teaching activities. For example, further research might explore the influence of activities from a different perspective such as analyzing students' utterances as corpus to examine their performance. As for practice, the findings of this study can be taken into consideration for teachers in the design of classroom activities, which may contribute to the improvement of students' proficiency.

Indisputably this study can not cover every factor that contributing to the effectiveness of classroom activities and there may exist other relevant studies and articles relating to this issue from different aspects, hence further investigations in the future are supposed to figure out more on this issue to improve the teaching and learning in English speaking in the context of Chinese EFL classrooms. 


\section{REFERENCES}

[1] Hedge, T. (2001). Teaching and learning in the language classroom (Vol. 106). Oxford, England: Oxford university press.

[2] Huang, X., \& Hu, X. (2016). Teachers' and Students' Perceptions of Classroom Activities Commonly Used in English Speaking Classes. Higher Education Studies, 6(1), 87-100.

[3] Humphries, S. C., Burns, A., \& Tanaka, T. (2015). "My head became blank and I couldn't speak": Classroom factors that influence English speaking. The Asian Journal of Applied Linguistics, 2(3), 164-175.

[4] Oradee, T. (2012). Developing speaking skills using three communicative activities (discussion, problem-solving, and role-playing). International Journal of Social Science and Humanity, 2(6), 533.

[5] Lim, S. L. (2017). Fluency and accuracy in spoken English - implications for classroom practice in a bilingual context. The English Teacher (23), 9.

[6] Zhang, X., \& Head, K. (2009). Dealing with learner reticence in the speaking class. ELT journal, 64(1), 1-9.

[7] Chou, M. H. (2018). Speaking Anxiety and Strategy Use for Learning English as a Foreign Language in Full and Partial English- Medium Instruction Contexts. TESOL Quarterly, 52(3), 611-633.

[8] Huang, H. T. D., \& Hung, S. T. A. (2013). Comparing the effects of test anxiety on independent and integrated speaking test performance. Tesol Quarterly, 47(2), 244-269.

[9] Tsiplakides, I., \& Keramida, A. (2009). Helping Students Overcome Foreign Language Speaking Anxiety in the English Classroom: Theoretical Issues and Practical Recommendations. International Education Studies, 2(4), 39-44.

[10] Mak, B. (2011). An exploration of speaking-in-class anxiety with Chinese ESL learners. System, 39(2), 202-214.

[11] Allwright, R. L. (1984). The importance of interaction in classroom language learning. Applied linguistics, 5(2), 156-171.

[12] Brittain, C. (2017). On learning English: The importance of school context, immigrant communities, and the racial symbolism of the English Language in understanding the challenge for immigrant adolescents.

[13] Anjomshoa, L., \& Sadighi, F. (2015). The importance of motivation in second language acquisition. International Journal on Studies in English Language and Literature (IJSELL), 3(2), 126-137.

[14] Smith, H., \& Higgins, S. (2006). Opening classroom interaction: the importance of feedback. Cambridge journal of education, 36(4), 485-502.

[15] Sigley, R. (2003). The importance of interaction effects. Language variation and change, 15(2), $227-253$.

[16] Pattanpichet, F. (2011). The effects of using collaborative learning to enhance students English speaking achievement. Journal of College Teaching \& Learning (TLC), 8(11), 1-10.

[17] Bashir, M., Azeem, M., \& Dogar, A. H. (2011). Factor effecting students' English speaking skills. British journal of arts and social sciences, 2(1), 34-50.

[18] Dornyei, Z., Alastair, H., \& MacIntrye, P. (2015). Introduction: Applying complex dynamic systems principles to empirical research on L2 motivation.

[19] Abrar, M., Mukminin, A., Habibi, A., Asyrafi, F., Makmur, M., \& Marzulina, L. (2018). "If our English isn't a language, what is it?" Indonesian EFL Student Teachers' Challenges Speaking English. The Qualitative Report, 23(1), 129-145.

[20] Rahman, A., \& Deviyanti, R. (2018). The correlation between students' motivation and their English speaking ability. Jurnal Ilmiah ESAI, 6(1), 66-83.

[21]Liu, T. Y., \& Chu, Y. L. (2010). Using ubiquitous games in an English listening and speaking course: 
Impact on learning outcomes and motivation. Computers \& Education, 55(2), 630-643.

[22]Liu, X. (2010). Arousing the College Students' Motivation in Speaking English through Role-Play. International Education Studies, 3(1), 136-144.

[23] Talley, P. C., \& Hui-Ling, T. (2014). Implicit and explicit teaching of English speaking in the EFL classroom. International Journal of Humanities and Social Science, 4(6), 38-45.

\section{AUTHOR'S BIOGRAPHIES}

Hangyu Zhang, a Chinese postgraduate student in Shanghai International Studies University pursuing a master's degree in English Applied Linguistics, and

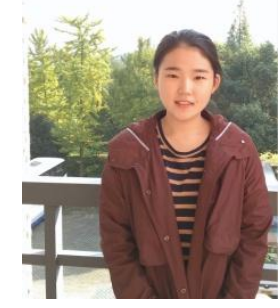
simultaneously a postgraduate student in Monash University in Master of TESOL. The current research direction is English teaching, focusing on classroom activities and online learning assistance.

Citation: Hangyu Zhang. "Effects of Different Classroom Activities on the English Speaking Proficiency of Chinese EFL Students International Journal on Studies in English Language and Literature (IJSELL), vol 8, no. 8, 2020, pp. 1-7. doi: http://dx.doi.org/10.20431/2347-3134.0808001.

Copyright: () 2020 Authors. This is an open-access article distributed under the terms of the Creative Commons Attribution License, which permits unrestricted use, distribution, and reproduction in any medium, provided the original author and source are credited. 